\title{
What Makes Informal Mentorship in the Medical Realm Effective?
}

Citation for published version (APA):

Mohtady, H. A., Könings, K., \& van Merrienboer, J. J. G. (2016). What Makes Informal Mentorship in the Medical Realm Effective? Mentoring and Tutoring: Partnership in Learning, 24(4), 306-317.

https://doi.org/10.1080/13611267.2016.1252111

Document status and date:

Published: 01/01/2016

DOI:

10.1080/13611267.2016.1252111

Document Version:

Publisher's PDF, also known as Version of record

Document license:

Taverne

Please check the document version of this publication:

- A submitted manuscript is the version of the article upon submission and before peer-review. There can be important differences between the submitted version and the official published version of record.

People interested in the research are advised to contact the author for the final version of the publication, or visit the DOI to the publisher's website.

- The final author version and the galley proof are versions of the publication after peer review.

- The final published version features the final layout of the paper including the volume, issue and page numbers.

Link to publication

\footnotetext{
General rights rights.

- You may freely distribute the URL identifying the publication in the public portal. please follow below link for the End User Agreement:

www.umlib.nl/taverne-license

Take down policy

If you believe that this document breaches copyright please contact us at:

repository@maastrichtuniversity.nl

providing details and we will investigate your claim.
}

Copyright and moral rights for the publications made accessible in the public portal are retained by the authors and/or other copyright owners and it is a condition of accessing publications that users recognise and abide by the legal requirements associated with these

- Users may download and print one copy of any publication from the public portal for the purpose of private study or research.

- You may not further distribute the material or use it for any profit-making activity or commercial gain

If the publication is distributed under the terms of Article $25 \mathrm{fa}$ of the Dutch Copyright Act, indicated by the "Taverne" license above, 


\title{
What Makes Informal Mentorship in the Medical Realm Effective?
}

\author{
Heba A. Mohtady, Karen D. Könings \& Jeroen J. G. van Merriënboer
}

To cite this article: Heba A. Mohtady, Karen D. Könings \& Jeroen J. G. van Merriënboer (2016) What Makes Informal Mentorship in the Medical Realm Effective?, Mentoring \& Tutoring: Partnership in Learning, 24:4, 306-317, DOI: 10.1080/13611267.2016.1252111

To link to this article: https://doi.org/10.1080/13611267.2016.1252111

曲 Published online: 24 Nov 2016.

Submit your article to this journal $₫$

Џll Article views: 395

Q View related articles $\asymp$

View Crossmark data \lceil

4 Citing articles: 4 View citing articles 


\title{
What Makes Informal Mentorship in the Medical Realm Effective?
}

\author{
Heba A. Mohtady \\ Zagazig University \\ Karen D. Könings and Jeroen J. G. van Merriënboer \\ Maastricht University
}

\begin{abstract}
Informal mentoring is based on a natural match between a junior individual and a senior one who share mutual interests. It usually aids in the professional and personal development of both parties involved. We reviewed the literature regarding factors that make informal mentoring effective within the medical realm, by searching a major academic search engine, Web of Knowledge, for the term "informal mentor*". Our main research questions concerned the factors that lead to a successful informal mentorship process. A salient finding arising is that the success of informal mentorships hinges on the communication skills of mentor and protégé, their level of commitment, and the chemistry between the partakers. Good informal mentorships impose requirements on both mentors and protégés and rest on shared expectations.
\end{abstract}

Keywords: mentor, protégé, mentorship, informal mentoring, medicine

\section{Introduction}

Mentoring is increasingly recognized as central to career development (Baker, 2015; Balmer, D'Alessandro, Risko, \& Gusic, 2011). In the medical field, mentoring has a marked effect on both the career advancement and personal development of protégés (Sambunjak, Straus, \& Marušić, 2006). Moreover, there is an increasing tendency to create mentorship opportunities in residency programs (Sambunjak, Straus, \& Marusic, 2010). Postgraduate medical education is largely a process of learning from experience which is encompassing mentoring and supervision (Swanwick, 2008; Teunissen et al., 2007). Mentoring varies from informal personal guidance to an assigned relationship within formal academic programs (Rose, Rukstalis, \& Schuckit, 2005). The latter is cemented to forge bonds between senior faculty and students or junior faculty, and to satisfy participants by developing their careers, which in turn may bolster faculty retention (Kashiwagi, Varkey, \& Cook, 2013). Nevertheless, in the existing literature, numerous researchers have reported difficulties in implementing widespread, effective formal mentoring programs, elaborating on a myriad of limitations and drawbacks while not necessarily providing an alternative (Ehrich, Hansford, \& Tennent, 2004;

Heba A. Mohtady, Faculty of Medicine, Director of Medical Education Centre, Zagazig University, Karen D. Könings and Jeroen J. G. van Merriënboer, Department of Educational Development \& Research and Graduate School of Health Professions Education, Maastricht University.

*Correspondence concerning this article should be addressed to Heba A. Mohtady, Faculty of Medicine, Director of Medical Education Centre, Zagazig University, Egypt. Emails: hebamohtady@hotmail.com, hebamohtady@gmail.com 
Pololi \& Knight, 2005). These limitations are suggested to stem from demographic factors such as gender (Sambunjak et al., 2006) and cultural background, especially for members of minority groups (Long, 1997). It may also stem from lack of coordination, support or funding for human resources development initiatives like mentoring (Douglas, 1997). Some institutions do not necessarily provide opportunities of formal mentoring to young physicians. These physicians therefore find themselves searching for professional development programs in other organizations (Singletary, 2005). Informal mentorship, by contrast, seems to elevate satisfaction levels and yield similar positive results to its formal counterpart (Shollen, Bland, Center, Finstad, \& Taylor, 2014). Consequently, we propose that informal mentorship might provide a more applicable alternative in environments where applying formal mentorship is not a practical possibility.

Informal mentoring pertains to relationships between mentors and protégés that arise without external organizational responsibility, management, or encouragement; thus, they are initially unintentional (Herrbach, Mignonac, \& Richebé, 2011; Hu, Thomas, \& Lance, 2008). Research on the dynamics of these informal relationships has shown that both parties realize that they share several commonalities and that collaboration between the two of them will lead to positive synergy (Young \& Perrewé, 2000). Informal mentorships are traditionally established by free will from both parties, who see mutual benefits in it for them (Ragins, Cotton, \& Miller, 2000). Meanwhile, there tends to be little resistance from the informal mentorships parties to engage in the non-imposed mentorship process in contrast with the formal relationships. Moreover, the researchers who investigated informal mentoring reported that protégés were more successful and efficient at their jobs (Ellinger, 2002), revealed a higher job satisfaction (Fagenson, 1989), and experienced more career support (Chao, Walz, \& Gardner, 1992). Such positive outcomes suggest that there is an advantage to informal mentorship that needs to be further highlighted. However, informal mentorship is not bound by guidelines or systems that parties to these relationships can consciously follow to consider themselves in an informal mentorship relationship. Consequently, establishing a single narrative of a functional dynamic becomes problematic to research (Williams, Levine, Malhotra, \& Holtzheimer, 2004).

Furthermore, the process by which informal mentorship is sustained requires a partnership-like bond, where both the mentor and the protégé commit to fulfilling their mutual and individual goals (McKenna \& Straus, 2011). Additionally, mentors specifically are suggested to contribute most to the evolving of the relationships when they value these relationships (Irby, 2013). There seems to be a set of preferred characteristics and desired roles of mentors and protégés, as well as barriers to effective mentorship that are key to studying informal mentorships (Sambunjak et al., 2010). However, there is a dearth of research exploring these factors, especially the dynamics by which they lead to positive results. Considering the importance of these informal mentorships, it seems crucial to further analyze the factors that enhance their existence. Through understanding the mechanisms by which these factors work, it is possible to promote the creation of environments that foster the development of successful informal mentorships (e.g. faculty development programs) (Shollen et al., 2014). We therefore seek to uncover the factors that affect-either positively or negatively-informal mentoring relationships within the medical realm. 


\section{Theory and Hypothesis}

To the authors' knowledge, there is no current comprehensive theoretical model for informal mentorship in the medical field. The Role Making Theory (Graen \& Cashman, 1975) has been used to analyze informal mentoring in the context of business organizations before (Welsh \& Wanberg, 2009). The theory stipulates that when two individuals are connected with a defined relationship within an organization, there is a possibility of transcending such a relationship into other roles, like informal mentoring. This progression takes place when both parties possess certain characteristics and skills that make them attractive choices for each other. The relevance of these characteristics seems to vary according to the field where the organization operates, as well as its policies regarding human resources development (Welsh \& Wanberg, 2009). Regarding informal mentoring in the medical field, we sought to explore answers to the following three questions through a literature review:

(1) What are the characteristics of effective informal mentors and what roles do they take to enhance the relationships with their protégés?

(2) What are the characteristics of effective protégés and what roles do they take to enhance the relationships with their mentors?

(3) Which barriers might negatively affect the process of informal mentoring?

\section{Method}

We searched the existing body of literature for relevant articles within the search engine Thomson Reuters Web of Knowledge/Web of Science Core Collection, which contains only peer-reviewed journals with an impact factor. Web of Science is the integrated version of the citation indices: Arts \& Humanities Citation Index, Social Sciences Citation Index, and Science Citation Index Expanded. To ensure an exhaustive search, we searched for the term "informal mentor*" in the period from 1988 to 2014. This yielded 266 results, of which, 76 journal articles were from the field of health sciences and medical fields (web of science research categories: "Health care sciences \& services", "Education: scientific disciplines", "Education and educational research" and "Psychology, educational". We comprehensively read these 76 articles for further screening based on fulfillment of our three inclusion criteria: An article had to report on: (a) informal mentoring, (b) concepts and basic elements affecting the mentoring process, and (c) studies conducted in a medical education or medical work context, such as medical schools, hospitals, and outpatient clinics. Articles were excluded when dealing with e-mentoring, peer mentoring, mentoring involving children, and informal mentoring concerted by doctors and patients. Only seven articles met these selection criteria. One of these was a review article and six were reports of empirical data. Finally, in-depth studying of all selected articles was done. This included comparing the methodologies followed by collecting all information related to our research three questions mentioned above.

\section{Results}

Before detailing our findings, we will briefly set out each of the articles' content. As for the six empirical studies, Healy, Glynn, Malone, Cantillon, and Kerin (2012) reported the results of a survey among 163 medical students and 216 surgical trainees who 
completed a 35-item questionnaire that included a number of traits associated with mentors and other role models. The participants ranked these traits according to their significance. Jackson et al. (2003) reported the qualitative results from interviews with 16 faculty members in the field of academic medicine. The interviews aimed at conceptualizing "informal mentoring" by analyzing the involvement of these faculty members with mentoring. Leslie, Lingard, and Whyte (2005) adopted a grounded theory approach to develop an explanation of informal mentoring in a pediatrics department. Participants were 10 clinical teaching faculty members. Shollen and colleagues (2014) surveyed members of a medical faculty on their satisfaction and productivity. The goal of their study was to unpack the influence that the perception of mentoring might have on either satisfaction or productivity. Further, Stamm and Buddeberg-Fischer (2011) explored the influence of mentoring during professional training on the career achievement of postgraduate doctors. This was done by investigating data obtained from a cohort of Swiss doctors in a longitudinal design. Finally, Steele, Fisman, and Davidson (2013) reported on a study using mixed sampling methodologies (questionnaires, focus groups and individual interviews with 175,8 , and 19 participants, respectively) at a school of medicine and dentistry to analyze the junior faculty's perspective on informal mentoring programs. Furthermore, a review article was written by Rose and colleagues (2005), with a focus limited to mentoring skills and guidelines for effective mentoring. They reviewed what skills mentors tend to possess. Moreover, the used methodology for their review was unclear and the review is no longer up-to-date. Our aim was far beyond the scope of the review by Rose as we aimed to find out what are the crucial characteristics of effective mentors and protégés, as well as factors that facilitate or hinder the process of effective informal mentoring.

We synthesized the findings from the seven articles and organized these into the following three categories that match our research questions: (a) mentors' characteristics and roles, (b) protégé's characteristics and roles, and (c) barriers that might hinder mentoring relationships.

\section{Characteristics and Roles of Effective Mentors}

Characteristics and roles of effective mentors can be defined at three different levels: the personal, interpersonal, and professional level. This reflects the idea that, in the field of academic medicine, mentoring relationships aims to support protégés in both their personal development and the development of their careers (McKenna \& Straus, 2011; Sambunjak et al., 2006). It also stresses that the effectiveness of informal mentorships hinges on interpersonal factors (Chao et al., 1992). In the following subsections, results of the reviewed papers will be summarized according to each of the specified levels.

Individual level. What surfaced as key mentor characteristics were those relating to leadership skills and the ability to motivate others (Jackson et al., 2003). It was preferred that mentors were easily accessible, reliable, and impartial (Leslie et al., 2005; Rose et al., 2005). What was also appreciated was their engagement, honesty, neutrality of opinion, and commitment to excellence (Healy et al., 2012). As regards age, Leslie and colleagues (2005) reported that junior participants did not consider a maximum age limit for their ideal mentor. That is, only 2 out of 10 participants believed that the sharing of experience necessary for a valuable mentoring relationship would be compromised if the 
age difference between mentor and protégé became too large. These exceptions, however, were reiterated by Steele and colleagues (2013) who found that junior faculty had a penchant for mentors "closer in age [...] and for mentors who speak the language" (Steele et al., 2013, p. e1134). The authors concluded that too large intergenerational variations could negatively affect the mentoring process. In sum, it is not the mentor's age that matters, but the age difference between mentor and protégé, who, consequently, should respect bounds.

Also gender appeared to weigh to varying extents. Leslie and colleagues (2005) reported that 3 out of 10 participants factored in gender when deciding on which mentor to choose. Interestingly, these were all mothers or women who had a desire to become one; their choice for a female mentor was grounded in the conviction that females would better appreciate their wish to have a family and to be successful in their profession at the same time. Moreover, the majority of the participants $(87.5 \%)$ in the study by Jackson and colleagues (2003) reported that the success of a match between mentor and protégé could be influenced considerably by the mentor's gender and race, although they were not preconditions. In cross-gender mentorships, keeping distinct margins appeared crucial to good mentoring relationships (Jackson et al., 2003). Finally, Stamm and Buddeberg-Fischer (2011) found that within the same work setting, more male than female junior doctors had mentors.

Interpersonal level. On an interpersonal level, the profile of an effective mentor appeared to require commitment to his/her protégés (Rose et al., 2005), in addition to a genuine interest in them and a keenness to establish a significant relationship (Jackson et al., 2003). What also emerged from the literature was that successful mentors communicate well and manage their existing relationship effectively (Healy et al., 2012). An effective mentoring relationship is one of mutual commitment that necessitates dedication, dynamic consistent care, and intermittent checks to identify constructive areas as well as areas in need of improvement (Rose et al., 2005). Jackson and colleagues (2003) emphasized that fruitful mentorships tend to develop informally, through relationships that evolve naturally. In fact, mentoring is fundamentally a two-person relationship that can be similar in complexity to the relationships between friends or family members. Jackson and colleagues (2003) highlighted the importance of "chemistry" (Jackson et al., 2003, p. 328) between mentor and protégé: Chances of mentoring relationships being successful increase if both partakers share the same concerns and morals.

Professional level. Mentors must not only have personal and interpersonal qualities, but they must also be able to help their protégés become a part of their professional community and develop their career. Not surprisingly, professional knowledge was an asset that protégés appreciated in their mentors: This was expressed in terms of being knowledgeable (Rose et al., 2005), having "clout" (Jackson et al., 2003, p. 328), and having good to excellent clinical knowledge (Healy et al., 2012). In addition, mentors should be skilled and experienced professionals, should be one or more stages ahead of their protégés, and have a fair amount of professional experience in their organization or field (Leslie et al., 2005; Rose et al., 2005). Other manifestations of professional mentor assets described in the literature were the readiness to act as an "academic parent" or "academic 
coach." (Jackson et al., 2003, p. 331). Where the former refers to the mentor selflessly promoting the protégés personal and professional development (e.g. by giving the protégé the credits for particular accomplishments), the latter denotes a mentor who offers counseling and support, inspires, and fosters the development of skills (Jackson et al., 2003; Shollen et al., 2014). In the surgical field, Healy and colleagues (2012) described three preferred characteristics of mentors. First, they should be enthusiastic about the practice of surgery and master good surgical techniques. Second, they must be able to make complex subjects accessible and teach in an exciting and stimulating way. Finally, they should have good research credentials, be able to kindle their protégés' interest in research and to involve them in their own research. Kram (1983) took a different stance and classified the roles that mentors fulfill at professional level into two categories: Guiding and supportive roles and career-related roles. The first category refers to devoted efforts to improve the protégé's sense of capability, uniqueness, and usefulness for the work that needs be done, for example: giving advice, creating a bond, role modeling, and showing appreciation (Kram, 1983). Mentors should challenge and inspire their protégés to achieve their long-term, specific and personal goals (Jackson et al., 2003; Kavanagh, Spence, Wilson, \& Crow, 2002; Lloyd, 1996; in Rose et al., 2005). They should also teach them how to achieve the right balance between work and private life and to keep these in harmony (Leslie et al., 2005; Shollen et al., 2014; Steele et al., 2013). Other activities related to such guiding and supportive roles include the facilitation of learning processes, the cultivation of intrinsic zeal and the monitoring of protégés' development. Mentors must enhance their protégés' self-esteem by giving affirmative responses and providing useful feedback (Jackson et al., 2003; Leslie et al., 2005). This is a crucial role of the mentor in supporting the protégé's academic work, including research and teaching, as well as their clinical performance (Shollen et al., 2014).

In the second category on career-related roles, we found attributes that help boost the protégés' career, for instance, "by providing sponsorship, exposure, visibility, coaching and protection" (Chao et al., 1992, p. 620). Protection is needed, for example, to advocate for protégés and to guard them from disadvantageous communications in the professional community (Jackson et al., 2003; Shollen et al., 2014). Sponsorship refers to the writing of recommendation letters and the deployment of one's skills so as to help the protégé "gain access to otherwise closed important academic circles" (Jackson et al., 2003 , p. 332). Further, the mentor generally provides guidance with networking, referrals, and preparing publications (Shollen et al., 2014). Finally, effective mentors also proved to play an important role in getting a promotion: They guided and supported their protégés along the way, helping them to develop themselves and to rank their priorities in work and in life (Jackson et al., 2003; Leslie et al., 2005; Shollen et al., 2014; Steele et al., 2013).

\section{Characteristics and Roles of Effective Protégés}

With regard to the typical traits of effective protégés, Leslie and colleagues (2005) found that protégés are generally well able to find the amount of support and direction they are looking for and to effectively recognize valuable sources of mentorship. At the same time, however, the prospect of asking others for help or support can arouse in the protégé feelings of imperfection. On an interpersonal level, the protégé requires a good 
share of perseverance and diligence to find the right mentor (Jackson et al., 2003). Those protégés taking action in order to find the appropriate mentor were mostly career-oriented. In the study by Jackson and colleagues (2003), participants pointed out how important it is to locate a suitable mentor early in the career and that this mentor should preferably be searched for from among different generations, internal and external domains, because finding the "right match" (Jackson et al., 2003, p. 333) can be difficult. One participant, moreover, suggested to schedule short meetings with colleagues who could potentially fulfill the role of mentor, whereas another participant recommended to search for a mentor outside the own institution. Protégés are advised to keep in mind that it may be difficult if not impossible to satisfy all mentoring requirements by way of one single mentoring experience (Jackson et al., 2003).

Another salient finding arising from the study by Leslie and colleagues (2005) was that all junior doctors indicated to have more than one informal mentor. In addition, their informal mentoring relationships were often hierarchical in nature and forged with work relations (i.e. mentors were above them in the hierarchy) or assessment relations (i.e. mentors also fulfilled the role of educational supervisor). Consequently, the strategies wielded to find a mentor were principally two: protégés either built relationships with colleagues who were a few years older or with senior physicians on the work floor, or they established bonds through conversations with senior physicians during regular performance appraisals. Either way, relationships usually developed spontaneously as part of the work atmosphere, without either of the partners clearly recognizing the mentorship (Leslie et al., 2005). On a professional level, Stamm and Buddeberg-Fischer (2011) found that gender, instrumentality, and extraprofessional concerns were important predictors of obtaining a mentor: male protégés with instrumental personality traits (energetic, strong-minded, and determined) and a strong career orientation found and preserved a mentor more often than others. In contrast, junior employees with many extraprofessional concerns (who, e.g. prioritized their family over work or were little flexible with regard to working hours) less often had a mentor.

Barriers to Mentoring. From the literature, it resulted that mentoring relationships are indeed susceptible to a number of barriers. Rose and colleagues (2005) zoomed in on barriers pertinent to the protégés. Some protégés, for instance, extremely appreciate or heavily rely on their mentor and must be reminded that they themselves are eventually accountable for their own development and for enhancing their relationships with other colleagues. These protégés might be served by advice so as to make clear to them that mentors are human beings who cannot explain everything and that it is necessary not to overly depend on their support and guidance. However, a heavy workload and responsibilities figured as potential impediments to the development and preservation of informal mentoring relationships (Leslie et al., 2005). Moreover, they identified two additional types of obstacle, dubbed (a) evaluation and (b) conflict of interest. The first one refers to mentors taking on an evaluative role, acting, for instance, not only as a mentor but also as a formal supervisor, which could inhibit the provision of support and assistance to a protégé. Many participants indicated that they would be careful or restrained in such a mentoring versus assessment give-and-take. The second type of obstacle-conflict of interest-involves the tension that junior doctors feel between their own expectations with regard to career advancement and research output on the one hand, and the clinical 
work expected of them on the other. All the while, they must balance work and private life, without detracting from their professional standards (Leslie et al., 2005).

Finally, Jackson and colleagues (2003) identified two other barriers that could potentially harm the mentoring relationship. The first one develops from protégés having more than one informal mentor, which could give rise to a multitude of viewpoints on the same issue, making it difficult for the protégé to decide on which course of action best to take. The second rare, yet important barrier concerns mentors taking advantage of their protégés. For instance, mentors may seek personal praise or credits for work done by their protégés, or even physically approach them in an inappropriate manner. As the protégé considers the mentor as an "academic parent" or teacher (Jackson et al., 2003, p. 331), such events will be highly distressing for him or her (Jackson et al., 2003).

\section{Discussion}

The value of informal mentoring relationships is widely accepted, as well as the conviction that both formal and informal mentoring are complementary to each other in a medical faculty, as they serve different needs. With respect to the first research question on characteristics and roles of informal mentors, we found that on an individual level, the most popular mentor is a leader and motivator who is easily approachable, reliable, understanding, engaged, honest, neutral, committed to excellence, and impartial. Favorable interpersonal characteristics of the mentor are that he/she is an effective communicator and manager of the relationship, enthusiastic, interested, dedicated, and committed. On a professional level, mentors are knowledgeable, skilled professionals who are often one or more stages ahead of their protégés. To help protégés become part of the professional community and develop their career, they fulfill both supportive and career-related roles.

With regard to the second question about the characteristics and roles protégés should typically possess to make the informal mentorship a success, our review brought to light several of these. In the first place, they should no longer think that asking others for help or support is a sign of their weakness. It is important that the right mentor is found and this requires perseverance and diligence, because the right match may not be easy to find. Protégés must search for them inside their own organization and beyond, and from among colleagues of the same generation who are one or more stages ahead of them, as well as from among senior individuals. Protégés should learn to concentrate their activities and must accept that one mentor alone may not be able to satisfy all their mentoring requirements.

Elaborating on the third research question concerning barriers that negatively affect informal mentoring relationships, our review brought to the fore that barriers can be found on either side of the partnership. Smooth dialogues can be barred, for instance, when protégés are overly dependent on their mentors or have many extraprofessional concerns. Barriers on the part of mentors relate to uneasy ties between mentoring and assessment, for example, when they have to combine their role of mentor with being a formal supervisor. Also the multitude of opinions arising from partnerships with more than one mentor proved to be a potential source of vulnerability.

Although our literature study has given interesting insights into relevant factors of informal mentorships within the medical realm, the paucity of available articles indicates that it is an element of work-based learning in medical schools, hospitals and outpatient 
clinics that has remained largely unexplored. Studies in which these dyadic relationships are discussed in depth are scant and there is a need for more research on how to stimulate effective informal mentorships. Research from domains outside the medical field, however, is more extensive and provides valuable directions for next steps to be taken in medical education research, especially with regard to the alignment of mentors' and protégés' perceptions in order to develop fruitful informal mentorship relations. This need for more research was already recognized by Welsh, Bhave, and Kim (2012), who showed that mentorships cannot reasonably be optimized by purely setting out the perceptions of mentors and protégés, just as our demarcation of their respective roles is not a panacea. They did so by investigating the extent to which prospective mentors and protégés concurred about them sharing an informal mentoring relationship. Since these relationships commonly rest on implicit understandings, it may so happen that mentor and protégé perceive their mentoring relationship differently. For example, it could be the case that only one of the partners acknowledges the existence of an informal mentorship (Welsh et al., 2012). Given the inherent dyadic nature of mentoring relationships, a failure to appreciate both perspectives will prevent one from fully understanding any such relationship (Eby, Durley, Evans, \& Ragins, 2008).

What is also important to note, is the fact that our present review only included articles that mainly approached informal mentorships from a fully established perspective, with little attention to how good relationships are actually forged - other than how protégés select their mentors. The motives and obstacles related to the initiation phase of the mentoring relationship are critical, as this phase scaffolds all subsequent phases (Hu et al., 2008). By the same token, however, a good understanding of later phases is equally important for sustaining the relationship. In the domain of management, Kram (1988) identified four phases in a mentoring relationship: (a) An initiation phase, in which the protégé is matched with the mentor, (b) a cultivation phase, in which the guidance and support the mentor provides to the protégé accumulates, (c) a separation phase, in which the protégé gradually becomes independent from his or her mentor due to either psychological or organizational changes, and (d) a redefinition phase, in which the mentorship relation is newly defined or ended (Kram, 1983). In addition, to these mentorship phases, the dynamics of mentoring relationships have also been researched in order to understand what it is that makes such relationships thrive and when exactly this happens (Eby, 2007; Fletcher \& Ragins, 2007; Kalbfleisch, 2007). Mentoring enactment theory, for instance, explains that mentor and protégé interactions involve "an ongoing series of relational challenges in the form of communication strategies and conversational goals that impact their relationships" (Ensher \& Murphy, 2011, p. 255). It was also found that the mentors and the protégés have different needs and expectations from their partners change as they both proceed through personal and career development phases. These needs and expectations may include some of the personality needs, evolving requirements and a number of skills and proficiencies concerning sympathy, interpersonal skills, and job learning (McGowan, Stone, \& Kegan, 2007). Consequently, a corresponding change in satisfaction with the mentorship can also be detected. Many researchers addressed the impact of relational challenges on mentoring relationships (Eby, 2007; Ensher \& Murphy, 2011; Fletcher \& Ragins, 2007). To date, however, the phases and dynamics of medical informal mentorships have never been fully understood.

Regarding practical implication of this literature study, it shows that informal mentoring has the capacity to be considered as an effective tool for professional development 
and contentment of both mentors and protégés. Medical schools and work environments are expected, therefore, to benefit from actively fostering an informal mentoring culture. Realizing that time and organizational constraints might affect the quality and presence of informal mentoring, we recommend that medical schools start allocating time and resources for mentors to perform tasks of such relationships. This way, the range of benefits that both informal and formal mentoring provide become widely accessible to potential protégés.

From the findings of our literature review, we can suggest that there remains a number of questions to be further studied. It would be of added value to develop a model that describes informal mentoring dynamics. Furthermore, future research needs to consider practical questions like how to stimulate effective informal mentorships and how to create environments that help good relationships prosper. A focus on how mentors' and protégés' perceptions, expectations, and preferences with respect to their mentoring relationship can be aligned and how possible discrepancies can be resolved or decreased is also a research need. Finally, further research is needed to understand the ways in which cultures as well as medical disciplines where medical schools operate influence the development of informal mentoring.

To conclude, in this literature study, we highlighted that an informal mentoring relationship is a responsibility that is shared by both partakers. Therefore, good communication skills, commitment, interactive fervor, and chemistry between the protégés and the mentors are key conditions for the success of informal mentorships. With respect to mentors, their professionalism, knowledge, motivation, reliability, honesty, and ability to communicate successfully are crucially required to develop such effective relationships. Regarding protégés, they are advised to avoid overdependence on and extreme appreciation of their mentors. Pressure at work, give-and-take and conflicting interests are barriers that may negatively affect these informal mentorships.

\section{Disclosure statement}

No potential conflict of interest was reported by the authors.

\section{Notes on contributors}

Heba A. Mohtady, MD, is a Professor at Faculty of Medicine \& Director of Medical Education Centre, Zagazig University, Egypt, her research interests include mentoring in culturally diverse medical environments, leadership development in medical education, and integrative approaches to quality management in medical education.

Karen D. Könings, $\mathrm{PhD}$, is an Associate Professor at the Department of Educational Development and Research and Graduate School of Health Professions Education, Maastricht University, Maastricht, the Netherlands. Her research focuses on student and teacher perspectives on education, and participatory design as an approach to account for different perspectives of stakeholders in the educational design process.

Jeroen J. G. van Merriënboer, $\mathrm{PhD}$, is professor of Learning and Instruction at the Department of Educational Development and Research and Research Director of the School of Health Professions Education at Maastricht University, the Netherlands. His research focuses on complex learning, instructional design and the use of technology in health professions education. 


\section{References}

Baker, V. L. (2015). People strategy in human resources: Lessons for mentoring in higher education. Mentoring \& Tutoring: Partnership in Learning, 23, 6-18.

Balmer, D., D’Alessandro, D., Risko, W., \& Gusic, M. E. (2011). How mentoring relationships evolve: A longitudinal study of academic pediatricians in a physician educator faculty development program. Journal of Continuing Education in the Health Professions, 31, 81-86.

Chao, G. T., Walz, P. M., \& Gardner, P. D. (1992). Formal and informal mentorships: A comparison on mentoring functions and contrast with nonmentored counterparts. Personnel Psychology, 45, 619-636.

Douglas, C. A. (1997). Formal mentoring programs in organizations: An annotated bibliography. Greensboro, NC: Centre for Creative Leadership.

Eby, L. T. (2007). Understanding relational problems in mentoring. In G. L. Rose \& B. R. Ragins (Eds.), The handbook of mentoring at work: Theory, research, and practice (pp. 323-344). Thousand Oaks, CA: Sage.

Eby, L. T., Durley, J. R., Evans, S. C., \& Ragins, B. R. (2008). Mentors' perceptions of negative mentoring experiences: Scale development and nomological validation. Journal of Applied Psychology, 93, 358-373.

Ehrich, L. C., Hansford, B., \& Tennent, L. (2004). Formal mentoring programs in education and other professions: A review of the literature. Educational Administration Quarterly, 40, $518-540$.

Ellinger, A. D. (2002). The workplace and educational institutions. In C. A. Hansman (Ed.), Critical perspectives on mentoring: Trends and issues (pp. 39-48). Columbus, OH: ERIC Clearinghouse on Adult, Career, and Vocational Education, Center on Education and Training for Employment, College of Education, the Ohio State University.

Ensher, E. A., \& Murphy, S. E. (2011). The mentoring relationship challenges scale: The impact of mentoring stage, type, and gender. Journal of Vocational Behavior, 79, 253-266.

Fagenson, E. A. (1989). The mentor advantage: Perceived career/job experiences of proteges versus non-proteges. Journal of Organizational Behavior, 10, 309-320.

Fletcher, J. K., \& Ragins, B. R. (2007). Stone center relational cultural theory. In G. L. Rose \& B. R. Ragins (Eds.), The handbook of mentoring at work: Theory, research, and practice (pp. 373-399). Thousand Oaks, CA: Sage.

Graen, G. B., \& Cashman, J. F. (1975). A role making model of leadership in formal organizations: A developmental approach. In J. G. Hunt \& L. L. Larson (Eds.), Leadership frontiers (pp. 143-165). Kent, OH: Kent State University Press.

Healy, N. A., Glynn, R. W., Malone, C., Cantillon, P., \& Kerin, M. J. (2012). Surgical mentors and role models: Prevalence, importance and associated traits. Journal of Surgical Education, 69, 633-637.

Herrbach, O., Mignonac, K., \& Richebé, N. (2011). Undesired side effect? The promotion of noncommitment in formal vs. informal mentorships. The International Journal of Human Resource Management, 22, 1554-1569.

Hu, C., Thomas, K. M., \& Lance, C. E. (2008). Intentions to initiate mentoring relationships: Understanding the impact of race, proactivity, feelings of deprivation, and relationship roles. The Journal of Social Psychology, 148, 727-744.

Irby, B. J. (2013). Editor's overview: Defining developmental relationships in mentoring for mentor/mentee dyads, for mentors, and for mentoring programs. Mentoring \& Tutoring: Partnership in Learning, 21, 333-337.

Jackson, V. A., Palepu, A., Szalacha, L., Caswell, C., Carr, P. L., \& Inui, T. (2003). Having the right chemistry. Academic Medicine, 78, 328-334.

Kalbfleisch, P. J. (2007). Mentoring enactment theory: Describing, explaining, and predicting communication in mentoring relationships. In B. R. Ragin \& K. E. Kram (Eds.), The handbook of mentoring at work: Theory, research, and practice (pp. 499-518). Los Angeles, CA: Sage.

Kashiwagi, D. T., Varkey, P., \& Cook, D. A. (2013). Mentoring programs for physicians in academic medicine. Academic Medicine, 88, 1029-1037.

Kavanagh, D. J., Spence, S. H., Wilson, J., \& Crow, N. (2002). Achieving effective supervision. Drug and Alcohol Review, 21, 247-252. 
Kram, K. E. (1983). Phases of the mentor relationship. Academy of Management Journal, 26, 608-625.

Kram, K. E. (1988). Mentoring at work: Developmental relationships in organizational life. Lanham, MD: University Press of America.

Leslie, K., Lingard, L., \& Whyte, S. (2005). Junior faculty experiences with informal mentoring. Medical Teacher, 27, 693-698.

Lloyd, B. (1996). How to be an effective educational supervisor. British Journal Hospital Medicine, 56, 585-587.

Long, J. (1997). The dark side of mentoring. The Australian Educational Researcher, 24, 115-133.

McGowan, E., Stone, E., \& Kegan, R. (2007). A constructive-development approach to mentoring. In B. Ragins (Ed.), The handbook of mentoring at work: Theory, research, and practice (pp. 401-425). Los Angeles, CA: Sage.

McKenna, A. M. \& Straus, S. E. (2011). Charting a professional course: A review of mentorship in medicine. Journal of the American College of Radiology, 8, 109-112.

Pololi, L., \& Knight, S. (2005). Mentoring faculty in academic medicine. Journal of General Internal Medicine, 20, 866-870.

Ragins, B. R., Cotton, J. L., \& Miller, J. S. (2000). Marginal mentoring: The effects of type of mentor, quality of relationship, and program design on work and career attitudes. Academy of Management Journal, 43, 1177-1194.

Rose, G. L., Rukstalis, M. R., \& Schuckit, M. A. (2005). Informal mentoring between faculty and medical students. Academic Medicine, 80, 344-348.

Sambunjak, D., Straus, S. E., \& Marušić, A. (2006). Mentoring in academic medicine. JAMA, 296, 1103-1115.

Sambunjak, D., Straus, S. E., \& Marusic, A. (2010). A systematic review of qualitative research on the meaning and characteristics of mentoring in academic medicine. Journal of General Internal Medicine, 25, 72-78.

Shollen, S. L., Bland, C. J., Center, B. A., Finstad, D. A., \& Taylor, A. L. (2014). Relating mentor type and mentoring behaviors to academic medicine faculty satisfaction and productivity at one medical school. Academic Medicine, 89, 1267-1275.

Singletary, S. E. (2005). Mentoring surgeons for the 21st century. Annals of Surgical Oncology, $12,848-860$.

Stamm, M., \& Buddeberg-Fischer, B. (2011). The impact of mentoring during postgraduate training on doctors' career success. Medical Education, 45, 488-496.

Steele, M. M., Fisman, S., \& Davidson, B. (2013). Mentoring and role models in recruitment and retention: A study of junior medical faculty perceptions. Medical Teacher, 35, e1130-e1138.

Swanwick, T. (2008). See one, do one, then what? Faculty development in postgraduate medical education. Postgraduate Medical Journal, 84, 339-343.

Teunissen, P. W., Scheele, F., Scherpbier, A. J. J. A., van der Vleuten, C. P. M., Boor, K., van Luijk, S. J., \& van Diemen-Steenvoorde, J A A M. (2007). How residents learn: Qualitative evidence for the pivotal role of clinical activities. Medical Education, 41, 763-770.

Welsh, E. T., Bhave, D., \& Kim, K. Y. (2012). Are you my mentor? Informal mentoring mutual identification. Career Development International, 17, 137-148.

Welsh, E. T., \& Wanberg, C. R. (2009). Launching the post-college career: A study of mentoring antecedents. Journal of Vocational Behavior, 74, 257-263.

Williams, L. L., Levine, J. B., Malhotra, S., \& Holtzheimer, P. (2004). The good-enough mentoring relationship. Academic Psychiatry, 28, 111-115.

Young, A. M., \& Perrewé, P. L. (2000). The exchange relationship between mentors and protégés: The development of a framework. Human Resource Management Review, 10, 177-209. 